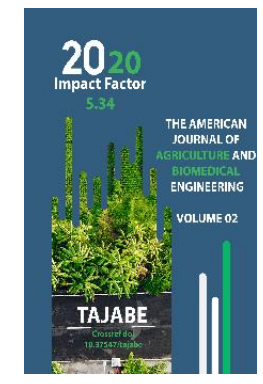

Copyright: Original content from this work may be used under the terms of the creative commons attributes 4.0 licence.

\section{Bioecological Properties Of Stevia Rebaudiana Bertoni In Introduction Conditions}

\author{
Begmatov Abdusamat Mamatkulovich
}

Termez State University, Head Of The Department Of Botany, Candidate Of Biological

Sciences, Associate Professor, Uzbekistan

Sattarov Abdumurod Sattarovich

Termez State University, Department Of Botany, Candidate Of Biological Sciences, Associate Professor, Uzbekistan

\title{
ABSTRACT
}

In the soil and climatic conditions of the Surkhandarya region, the biological characteristics of the tropical plant S. rebaudiana at the stages of ontogenesis have been studied for the first time. The regularities of growth and development, the timing of the onset of the phases of budding, flowering, fruiting during the propagation of plants by seed have been established.

\section{KEYWORDS}

Stevia rebaudiana Bert., introduction, seed biology, seed productivity, stevioside.

\section{INTRODUCTION}

Stevia rebaudiana is used in the treatment of patients with diabetes, skin, digestive, urinary genital system and other diseases. By growing Stevia rebaudiana in Uzbekistan, it is planned to launch the production of drugs used in the treatment of these diseases in the future. The introduction of medicinal plants - not only reduces the cost of imported raw materials, but also enriches the biodiversity of our local environment - and partially meets the demand of the population for medicinal plants [1], [2]. Stevia rebaudiana leaf is also used in the manufacture of canned and confectionery products. Nowadays, there is a growing 
demand for the use of natural resources that give a sweet taste and do not harm human health [3]. One such source is the Stevia rebaudiana plant. In countries such as the United States, France, South Korea, Canada, Russia, Ukraine, China, 6-7\% stevioside in the leaves of Stevia rebaudiana has been used for decades in the manufacture of confectionery, various medicinal drinks, canned food. Also, its use as a medicine gives positive results.

Steviozid is the main sweet-tasting compound of Stevia rebaudiana leaf, which has been found to be free of mutagenic and carcinogenic substances and has therefore been approved by healthcare organizations for its widespread use.

Stevia rebaudiana is a perennial herb of the Bertoni family of Asteraceae. The plant is native to Paraguay and has been used by locals for more than 1,500 years. Adapted to the tropics of South America, the leaves of this plant contain $6-7 \%$ stevioside. It is $200-300$ times sweeter than the sugar consumed, though it provides low calories, has no power supply. Currently, more than 15 countries (USA, UK, France, Japan, China, South Korea, Canada, Russia, Ukraine, etc.) use stevia on a large scale.

Surkhandarya region of the Republic of Uzbekistan is located in the southernmost part of the country. It is also located in the southern part of Central Asia, its territory corresponds to the arid subtropical climate zone. The territory of the region is crossed by $37^{\circ} 10 \mathrm{l}-39^{\circ} 021$ north latitude and $66^{\circ} 321-68^{\circ} 251$ east latitude lines.

\section{MATERIALS AND METHODS}

At the present time, the importance of plant introduction is not diminishing, but still opens up new prospects for the development of plant resources on the planet. The role of plant introduction is also invaluable in the process of selection and testing of plants that are early maturing, fertile, resistant to various diseases and pests, adapted to local soil-climatic conditions and have other beneficial economic characteristics [4]. It is of great importance to study the individual development, i.e. growth and development, of ontogenesis of the introduced S. rebaudiana. How the plants grow and develop in the new conditions is one of the important indicators of adaptation. The adaptive characteristics of acclimatized species are manifested in the early stages of plant ontogeny. Therefore, the study of the ontogenesis of the $\mathrm{S}$. rebaudiana plant is of theoretical and practical importance, as the study of the early stages of plant ontogeny allows us to think about its subsequent growth and development. It undergoes a number of morphological, anatomical, physiological and biochemical changes in the ontogenesis of any plant.

Observations revealed that there was a difference between the potential and actual seed yields of S. rebaudiana. Thus, in 2017-2019, the coefficient of seed yield in S. rebaudiana in the first, second and third growing years in the conditions of Shurchi district of Surkhandarya region was $35.11-38.50 \%$, ie the seeds of $\mathrm{S}$. rebaudiana in late November and early December. cooked (Table 1). 
1-table

Seed productivity of S. rebaudiana

(at the base of the plant, $n=10$ )

\begin{tabular}{|c|c|c|c|c|c|c|}
\hline $\begin{array}{c}\text { Observed } \\
\text { years, plant } \\
\text { age }\end{array}$ & $\begin{array}{l}\text { The } \\
\text { number of } \\
\text { flowers in } \\
\text { the basket }\end{array}$ & $\begin{array}{c}\text { The } \\
\text { number } \\
\text { of } \\
\text { baskets }\end{array}$ & PUM & HUM & $\begin{array}{c}\text { UMK, } \\
\%\end{array}$ & $\begin{array}{l}\text { Absolyut } \\
\text { seed } \\
\text { weight, g }\end{array}$ \\
\hline 2017-1 & $4,92 \pm 0,27$ & $\begin{array}{r}135 \\
\pm 1,6\end{array}$ & $\begin{array}{l}664,2 \\
\pm 8,6\end{array}$ & $\begin{array}{r}234,3 \\
\pm 5,1\end{array}$ & 35,23 & $\begin{array}{l}0,263 \\
\pm 0,02\end{array}$ \\
\hline 2018- 1 & $4,96 \pm 0,2$ & $\begin{array}{r}124 \\
\pm 2,8\end{array}$ & $\begin{array}{l}615,1 \\
\pm 7,3\end{array}$ & $\begin{array}{r}228 \\
\pm 7,2\end{array}$ & 37,07 & $\begin{array}{l}0,280 \\
\pm 0,05\end{array}$ \\
\hline 2019- 1 & $4,98 \pm 0,03$ & $\begin{array}{l}109 \\
\pm 2,3\end{array}$ & $\begin{array}{l}542,8 \\
\pm 6,1\end{array}$ & $\begin{array}{l}209 \\
\pm 7,7\end{array}$ & 38,50 & $\begin{array}{l}0,273 \\
\pm 0,03\end{array}$ \\
\hline 2017- 2 & $4,86 \pm 0,09$ & $\begin{array}{l}1792,2 \\
\pm 17,2\end{array}$ & $\begin{array}{c}8709,1 \\
\pm 6,6\end{array}$ & $\begin{array}{l}3215,1 \\
\pm 10,7\end{array}$ & 36,88 & $\begin{array}{l}0,255 \\
\pm 0,03\end{array}$ \\
\hline 2018- 2 & $4,94 \pm 0,05$ & $\begin{array}{r}1727 \\
\pm 15,6\end{array}$ & $\begin{array}{l}8531,4 \\
\pm 13,8\end{array}$ & $\begin{array}{r}3239 \\
\pm 13,5\end{array}$ & 37,96 & $\begin{array}{l}0,295 \\
\pm 0,03\end{array}$ \\
\hline 2019- 2 & $5,02 \pm 0,2$ & $\begin{array}{l}2017 \\
\pm 7,1\end{array}$ & $\begin{array}{r}10125,3 \\
\pm 8,4\end{array}$ & $\begin{array}{r}3692,1 \\
\pm 12,4\end{array}$ & 36,39 & $\begin{array}{r}0,275 \\
\pm 0,03\end{array}$ \\
\hline $2017-3$ & $4,88 \pm 0,2$ & $\begin{array}{l}4651,1 \\
\pm 18,9\end{array}$ & $\begin{array}{r}22696,8 \\
\pm 26,7\end{array}$ & $\begin{array}{r}8461 \\
\pm 32,4\end{array}$ & 37,28 & $\begin{array}{r}0,275 \\
\pm 0,04\end{array}$ \\
\hline
\end{tabular}


The American Journal of Agriculture and Boimedical Engineering (ISSN - 2689-1018)

Published: October 31, 2020 | Pages: 63-68

\begin{tabular}{|c|c|c|c|c|c|c|}
\hline 2018-3 & $4,90 \pm 0,2$ & 5400,1 & 26460,1 & 9291,2 & 35,11 & 0,287 \\
& & $\pm 12,8$ & $\pm 17,1$ & $\pm 18,5$ & & $\pm 0,04$ \\
\hline $2019-3$ & $4,96 \pm 0,06$ & 5491,3 & 27235,3 & 9891,1 & 36,33 & 0,285 \\
& & $\pm 16,8$ & $\pm 22,5$ & $\pm 24,8$ & & $\pm 0,05$ \\
\hline
\end{tabular}

S currently grown in the field. the ripening ethylagn seeds of rebianaiana are obtained. In 2019, 3 to $200 \mathrm{~kg}$ of dark seed was grown from field-care plants (Table 2).

Table 2

S common and useful air temperature. rebaudiana's

impact on growth and development

\begin{tabular}{|c|c|c|c|c|c|c|}
\hline \multirow[b]{2}{*}{$\begin{array}{l}\text { Growth and } \\
\text { developme } \\
\text { nt } \\
\text { thorn bushes }\end{array}$} & \multicolumn{2}{|c|}{2017 year } & \multicolumn{2}{|c|}{2018 year } & \multicolumn{2}{|c|}{2019 year } \\
\hline & $\begin{array}{c}\text { Total } \\
\text { temperat } \\
\text { ure, }{ }^{\circ} \mathrm{C}\end{array}$ & $\begin{array}{c}\text { Useful } \\
\text { temperatur } \\
\text { e sum, }{ }^{\circ} \mathrm{C} \text {, } \\
\text { day }\end{array}$ & $\begin{array}{c}\text { Total } \\
\text { temperat } \\
\text { ure, }{ }^{\circ} \mathrm{C}\end{array}$ & $\begin{array}{c}\text { Useful } \\
\text { temperatur } \\
\text { e sum, }{ }^{\circ} \mathrm{C} \text {, } \\
\text { day }\end{array}$ & $\begin{array}{c}\text { Total } \\
\text { temperat } \\
\text { ure, }{ }^{\circ} \mathrm{C}\end{array}$ & $\begin{array}{c}\text { Useful } \\
\text { temperatur } \\
\text { e sum, }{ }^{\circ} \mathrm{C} \text {, } \\
\text { day }\end{array}$ \\
\hline $\begin{array}{l}\text { The } \\
\text { beginning of } \\
\text { the growing } \\
\text { season }\end{array}$ & 431,7 & $\begin{array}{l}181,8 \\
22.03 .\end{array}$ & 390,8 & $\begin{array}{l}215,3 \\
10.03\end{array}$ & 473,3 & $\begin{array}{l}254,9 \\
12.03\end{array}$ \\
\hline Budding & 4442,4 & $\begin{array}{l}4074,3 \\
23.08 .\end{array}$ & 4608,2 & $\begin{array}{l}4429,5 \\
20.08 .\end{array}$ & 4278,7 & $\begin{array}{l}4060,3 \\
27.08\end{array}$ \\
\hline Flowering & 4911,2 & $\begin{array}{l}4543,1 \\
10.09 .\end{array}$ & 4945 & $\begin{array}{l}4714,2 \\
08.09 .\end{array}$ & 4796,9 & $\begin{array}{l}4555,7 \\
02.09 .\end{array}$ \\
\hline $\begin{array}{l}\text { Seed } \\
\text { ripening }\end{array}$ & 5591,8 & 5139,7 & 5541,9 & 5363,2 & 5602,1 & 5188,1 \\
\hline
\end{tabular}


The American Journal of Agriculture and Boimedical Engineering (ISSN - 2689-1018)

Published: October 31, 2020 | Pages: 63-68

\begin{tabular}{|c|c|c|c|c|c|c|}
\hline & 10.10. & & 08.10. & & 10.10. \\
\hline $\begin{array}{c}\text { The end of } \\
\text { the growing } \\
\text { season }\end{array}$ & 6302,7 & 5498,2 & 6346,8 & 5998,9 & 6126,9 & 5836,3 \\
& 15.12. & & 10.12. & & 06.12 \\
\hline
\end{tabular}

\section{RESULTS AND DISCUSSIONS}

The end of the vegetation was determined on December 15, December 10, and December 6, respectively. In 2017, the vegetation of S. rebaudiana started later than in other years $(2018,2019)(22.03 .2017)$. This can be explained by the fact that the air temperature from March 16 to March 18 (low) is 5, $105 \mathrm{C}$ to $7.6 \mathrm{C}$, the relative humidity is $51-71 \%$. Found that the $3-$ day climatic factors were below $100 \mathrm{C}$. As of March 29, the air temperature was $11.5 \mathrm{C}$ and the relative humidity was $44 \%$. In 2018 , the generative period of the plant began early as the FHY sum (4429.5C) was slightly higher. In general, the buds on the underground branch of the plant began to grow for 11-13 days, starting from the second decade of March. Budding lasted from late August to late November, flowering from early September to early December, and seed production lasted from the second day of October to the first ten days of December. In the process of studying the bio ecological properties of plants introduced in new conditions, it is important to study the growth rate, the rhythm of seasonal development and their relationship to key environmental factors.

\section{CONCLUSION}

1. The short-lived tropical plant S. rebaudiana introduced in Surkhandarya region goes through all stages of ontogeny. The sum of the beneficial temperatures affected only the timing of the onset of vegetation. The onset of budding and flowering was explained by a shortening of the day length.

2. In the conditions of Surkhandarya region, the main seed mass of $\mathrm{S}$. rebaudiana ripens in November. Anemochoria is typical for the plant, and about $200 \mathrm{~kg}$ of seeds were harvested from 1 hectare.

\section{REFERENCE}

1. Begmatov A. M.,.., Allamuratov A. L. Flask of the city conditions palandeng (sieboldnia) bioecological features. Internauka Moscow. 2019. - Pp. 51-53.

2. Begmatov a.m., rakhmatova $M$. U. Bioecological features of Glycyrrhiza L.//Modern scientific research and development, No. 3 (20). Moscow, 2018. Pp. 110-113.

3. Begmatov A.M., Sharipov A.E., Rakhmatova M.He Bioecological features of Stevia rebianaiana Bertoni in the conditions of the surkhandarya region/ / integration of fundamental science and practice: problems and prospects materials of the Republican scientific-practical conference. - Tashkent, 2018.

What? 156-157. 
The American Journal of Agriculture and Boimedical Engineering (ISSN - 2689-1018)

Published: October 31, 2020 | Pages: 63-68

Doi: https://doi.org/10.37547/tajabe/Volumeo2Issue10-11

2020: $5 \cdot 34$

OCLC - 1121105746

4. DjumaevX. Q., Zenkevich I.G., Begmatov A.M., Sattarov A.S. Composition of essential oils of sage salvia sclarea I. and their changes depending on the vegetative phases of development. Scientific Bulletin of Namangan State University, 2019. №6. P. 183-193. 